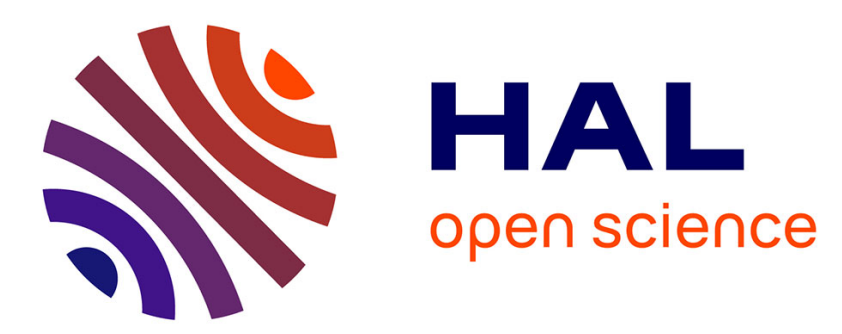

\title{
A brief tribute to slowness in science
}

Rafael Munoz Tamayo

\section{To cite this version:}

Rafael Munoz Tamayo. A brief tribute to slowness in science. 2018. hal-02786714

\section{HAL Id: hal-02786714 \\ https://hal.inrae.fr/hal-02786714}

Preprint submitted on 5 Jun 2020

HAL is a multi-disciplinary open access archive for the deposit and dissemination of scientific research documents, whether they are published or not. The documents may come from teaching and research institutions in France or abroad, or from public or private research centers.
L'archive ouverte pluridisciplinaire HAL, est destinée au dépôt et à la diffusion de documents scientifiques de niveau recherche, publiés ou non, émanant des établissements d'enseignement et de recherche français ou étrangers, des laboratoires publics ou privés. 


\section{A brief tribute to slowness in science*}

\section{Rafael Muñoz-Tamayo,}

UMR Modélisation Systémique Appliquée aux Ruminants, INRA, AgroParisTech, Université Paris-Saclay, 75005, Paris, France.

E-mail: rafael.munoz-tamayo@inra.fr

November 2018

J ublish or perish: is it the right motto? The answer to this question should be a strong NO. But we already know that this is not the case. I look at the different research calls in which I have participated to get funding. In the CV section, I find the following phrase: I have a solid track record with $\mathrm{W}$ publications, of which $\mathrm{X} \%$ are published in $\mathrm{Q} 1$ journals. I have $\mathrm{Y}$ citations and my h-index is $\mathrm{Z}$. Is this the right information that defines my path? Are these the correct measurements of my research? I hope not. Even so, I am the one who has written these phrases and nobody has forced me to write them like that. The why goes with the following essay.

Let's imagine for a moment the following cliché of the scientist: a man with dishevelled hair, wide trousers, the collar of the shirt badly put, the glasses are somewhat fogged. The lenses reflect a lost look towards an apple tree. Time passes slowly. Ideas are carefully woven in a galaxy of neurons. The sun has hidden and our scientist takes the bicycle to go home. The next morning, when passing close to the river, the song of a bird makes him think in certain harmonics.

Well, this image encloses the implicit sense of

${ }^{*}$ This text is an updated translated version of the essay: Breve elogio a la lentitud en ciencia. (2016). In: Ciencia y Humanismo 50 años Revista Aleph (1996-2016), pp. 473478, C.E. Ruiz (Ed.) Ed. Universidad de Caldas, Colombia [Muñoz-Tamayo(2016)]. a spiritual work, guided by the essence of asking, perhaps, by the utopian idea of finding a treasure that might change humankind. For some scientists, the utopia will come true. For others, the utopia will remain as a driving force. However, the reality faced by the scientist, in particular the young (early-career) scientist, is another one.

\section{Metrics and misadventures}

As it has occurred in the evaluation process of various public sector institutions [Ogien(2013)], the number has gained an overwhelming importance in the evaluation of research. In principle, the concept of measuring the research work responds to the natural need to have evaluation standards, which is absolutely valid and pertinent. The great difficulty in this procedure is that the measure implies science to be defined as a product and, in this transformation of sense, the legitimacy of science (and of the scientist who performs it) is hereof validated by the measure, in a process that is unscientific, subjective, and secretive [PLoSMedicine-Editors(2006)]. But science is not a product.

Currently, the performance of a scientist is mainly measured by their publications: the number of articles published, the number of times their articles are cited by peers, and the prestige of the journals where the articles have been published. The prestige of a journal is often assessed by an indicator 
known as the impact factor (IF) that measures the average number of citations for each article published in the journal. In addition to the IF, the scientist performance is measured by the $\mathrm{H}$ index that attempts to measure the impact of the work published in the scientific community. An index $\mathrm{H}$ of value $n$ implies that the scientist has at least $n$ published articles that have been cited at least $n$ times.

The IF, the index $\mathrm{H}$, the number of articles and citations are currently the main criteria for promotion and evaluation both in competitions to obtain research positions and in the calls for research projects and scholarships at national and international level. Although these indicators might correlate with the quality of scientific work, several authors have identified the limitations and dangers of these indicators to assess the value of published research work [Seglen(1997), PLoSMedicine-Editors(2006), Lawrence(2007), Brembs et al.(2013), Paulus et al.(2018)]. From these criticisms, it is worth to mention the San Francisco Declaration on Research Assessment (DORA, https://sfdora.org/read/) [Cagan(2013)] initiative to discourage and combat the misuse of IF to evaluate the work of individual scientists.

Evaluation is necessary to guarantee the quality of science, and publishing is undoubtedly a central aspect of the scientific work, which also implies a source of satisfaction and recognition. However, publication is not the raison d'être of science. The disproportionate importance of publications in the scientific career is a dangerous threat that promotes a science where the discovery of truth is diminished by the desire of publishing [Lawrence(2007), Park et al.(2014)]. This phenomenon is recognized in the scientific community under the broadly spread materialistic motto publish or perish, and is accompanied by the IF obsession (impactitis) [Casadevall and $\operatorname{Fang}(2015)$ ]. And in this race towards publication, the integrity of science has been jeopardized by ethical misconduct from the scientific community (including Nobel prizes) [Martinson et al.(2005)]. In fact, a significant number of cases of falsification [Nosek et al.(2012)] and data fabrication have been reported in various scientific domains such as the Schön case (2002) in physics, the Stapel case (2011) in psychology and the Voinnet case (2015) in biology (communication by Patricia Volland-Nail http://fr.slideshare.net/pvolland). A gray cloud covers a profession that should enlighten our knowledge of the world.

The pressure exerted by the eagerness to publish affects the entire scientific community, but it shows a marked importance for the young researcher, who must face a hypercompetition to be consolidated as a scientist through funding grants and job competitions in a selection system strongly based on article publication indicators [Schäfer et al.(2011), Farlin and Majewsky(2013), Schekman(2013)]. This system tends to favour short-term applied research projects over long-term basic research projects [Haroche(2012)]. The pressure to publish at any price is undoubtedly detrimental to the quality of science and the development of the profile of the researcher, who from the early stage of their career sees how the first utopia becomes overshadowed by mercantile factors. In the silence, the imposter syndrome [Woolston(2016)] comes to disturb our thoughts. In this context, it is very valuable, as statement of principle, the decisions of the ASM journals and eLife of removing the information of the IF on their websites as a declaration of the IF inappropriate use and of the need of alternative research metrics [Schekman and Patterson(2013), Casadevall et al.(2016)]. It must be kept in mind, however, that any kind of journal-based assessment will remain flawed in some way and not exempted of the impact factor fallacies discussed by [Paulus et al.(2018)].

\section{A look at the slowness}

The responsibility of changing the engine that drives the scientific activity is not only the resultant of the bureaucratic and political strategies of research centres, and the funding and evaluation agencies of research institutions in each country. The responsibility is also ours who have allowed the implantation of the tremendous reliance on journal citation metrics as indicators of the importance of our research [Casadevall and Fang(2015)]. Although this essay illustrates a tendency that is detrimental to the integrity of science, it would be irresponsible to affirm that all scientists follow the doctrine of publishing or perishing and that the conquest of knowledge, as the first motivation, occupies a marginal place. Many researchers continue defending the integrity of science, and resist to the view of science as a mercantile product. 
Science will continue its primary role of advancing knowledge and serve society. Modern times call for engaged scientists that, as proposed by the French collective Sciences en Marche (http://sciencesenmarche.org), defend the scientific method against preconceived opinions and ideologies, and strengthen the dialogue between science and society. Within this context, a switch of direction is needed for promoting beauty and integrity in science. In addition to the actions necessary in the hiring, promotion and funding decisions adopted in scientific institutions, a change of attitude on the part of the scientific community is necessary. We must return to the essential scientific values over the accumulation of publications, and thus be able to eradicate the impactitis medical condition [Casadevall and Fang(2014)]. We must defend the principles of scientific integrity [Letellier(2016)] and engage in conducting a responsible, reliable and traceable research. And for that, we must beat the rush, not to fall into lethargy, but to strengthen our thinking. Science and the scientist need time. Time even to misunderstand each other (http://slow-science.org/). Time to read, not only the work of our scientific peers, but also to read and re-read Aristotle, Khant, Khun, Popper, Russell and modern philosophers. Time to read Mafalda, Calvin and Hobbes.

We need to beat the rush, to position utopia as the first place. Promote ethical behaviour through training and discussion spaces for consolidating, at the early stage of the scientist career, an awareness of what the essential scientific values are. An awareness that translates into action of resistance to defend the humanistic role of science.

Beat the rush, to look at science as well as art [Barnes(1995)]. Beat the rush, to make the irrational emerge, to give way to creative thinking and give rise to serendipity: that of Alexander Flemming and Isaac Newton, and be able to shout Eureka all over the world.

Beat the rush, to strengthen the genius and keep alive the spirit of a child who asks questions over and over ${ }^{1}$. Beat the rush, to experience the joy of understanding: what is gone, what is on the way. ${ }^{2}$.

\footnotetext{
${ }^{1}$ As the child of the song Escaramujo by Silvio Rodríguez.

${ }^{2}$ From the poem Five Lines by Nazim Hikmet.
}

\section{References}

[Barnes(1995)] Barnes, C. J., 1995. The Art of Catchment Modeling - What Is a Good Model. Environment International 21, 747-751.

[Brembs et al.(2013)] Brembs, B., Button, K., Munafò, M., 2013. Deep impact: unintended consequences of journal rank. Frontiers in human Neuroscience 7, 291.

[Cagan(2013)] Cagan, R., 2013. The San Francisco declaration on research assessment. Disease models \& mechanisms 6, 869-870.

[Casadevall et al.(2016)] Casadevall, A., Bertuzzi, S., Buchmeier, M. J., Davis, R. J., Drake, H., Fang, F. C., Gilbert, J., Goldman, B. M., Imperiale, M. J., Matsumura, P., McAdam, A. J., Pasetti, M. F., Sandri-Goldin, R. M., Silhavy, T., Rice, L., Young, J.-A. H., Shenk, T., 2016. Asm journals eliminate impact factor information from journal websites. Applied and Environmental Microbiology 82, 5479-5480.

[Casadevall and Fang(2014)] Casadevall, A., Fang, F. C., 2014. Causes for the persistence of impact factor mania. mBio 5, e00064-e00014.

[Casadevall and Fang(2015)] Casadevall, A., Fang, F. C., 2015. Impacted science: Impact is not importance. mBio 6 .

[Farlin and Majewsky(2013)] Farlin, J., Majewsky, M., 2013. Performance indicators: The educational effect of publication pressure on young researchers in environmental sciences. Environmental Science \& Technology 47, 2437-2438, pMID: 23461664.

[Haroche(2012)] Haroche, S., 2012. The secrets of my prizewinning research. Nature News 490, 311.

[Lawrence(2007)] Lawrence, P. A., 2007. The mismeasurement of science. Current biology 17, R583-R585.

[Letellier(2016)] Letellier, L., 2016. Integrity and responsibility in research practices. a guide. Tech. rep., CNRS Ethics Committee (COMETS).

[Martinson et al.(2005)] Martinson, B. C., Anderson, M. S., de Vries, R., 2005. Scientists behaving badly. Nature 435, 737-738. 
[Muñoz-Tamayo(2016)] Muñoz-Tamayo, R., 2016. Breve elogio a la lentitud en ciencia (A brief tribute for slowness in science). In: Ruiz, C. E. (Ed.), Ciencia y Humanismo 50 años Revista Aleph (1996-2016). Editorial Universidad de Caldas, Manizales, Colombia, pp. 473-478.

[Nosek et al.(2012)] Nosek, B. A., Spies, J. R., Motyl, M., 2012. Scientific utopia: Ii. restructuring incentives and practices to promote truth over publishability. Perspectives on Psychological Science 7, 615-631.

[Ogien(2013)] Ogien, A., 2013. Désacraliser le chiffre dans l'évaluation du service public. Sciences en questions. Quae Editions.

[Park et al.(2014)] Park, I. U., Peacey, M. W., Munafo, M. R., 2014. Modelling the effects of subjective and objective decision making in scientific peer review. Nature 506, 93-96.

[Paulus et al.(2018)] Paulus, F. M., Cruz, N., Krach, S., 2018. The impact factor fallacy. Frontiers in psychology 9, 1487.

[PLoSMedicine-Editors(2006)] PLoSMedicineEditors, Jun. 2006. The impact factor game. it is time to find a better way to assess the scientific literature. PLoS medicine 3, e291.

[Schäfer et al.(2011)] Schäfer, R. B., Cooke, S. J., Arlinghaus, R., Bonada, N., Brischoux, F., Casper, A. F., Catford, J. a., Rolland, V., nov 2011. Perspectives from early career researchers on the publication process in ecology - a response to Statzner \& Resh (2010). Freshwater Biology 56, 2405-2412.

[Schekman(2013)] Schekman, R., 2013. How journals like nature, cell and science are damaging science. The Guardian.

[Schekman and Patterson(2013)] Schekman, R., Patterson, M., 2013. Reforming research assessment. eLife 2, e00855, original DateCompleted: 20130524, Original DateCompleted: 20140206.

[Seglen(1997)] Seglen, P. O., 1997. Why the impact factor of journals should not be used for evaluating research. BMJ 314, 49802.

[Woolston(2016)] Woolston, C., 2016. Psychology: Faking it. Nature 529, 555-557. 